\title{
Supporting Preservice Chemistry Teachers to Learn Islam and Science Using Moodle
}

\author{
Buchori Muslim \\ Department of Chemistry \\ Education \\ UIN Syarif Hidayatullah \\ Jakarta, Indonesia \\ buchorimuslim@uinjkt.ac.id
}

\author{
Reni Nofianti \\ Department of Chemistry \\ Education \\ UIN Syarif Hidayatullah \\ Jakarta, Indonesia \\ reninofianti9@gmail.com
}

\author{
Siti Suryaningsih \\ Department of Chemistry \\ Education \\ UIN Syarif Hidayatullah \\ Jakarta, Indonesia \\ siti.suryaningsih@uinjkt.ac.id
}

\begin{abstract}
Information and communication technology or ICT (Information and Communication Technology) is growing very rapidly. This has a tremendous impact on various sectors of life, one of which is education, then the application of ICT becomes a mandatory choice that must be applied. But the problem of technology still plays a small role in learning and teaching. This study aims to develop web-based learning media in Islamic and Science courses in the face of 21st-century challenges. The research and development method uses a 4D model by following the path of Thiagarajan et al. which has four stages, namely define, design, development, and disseminate, but researchers did not go through the disseminate stage. The assessment was done in the form of media and pedagogic validation, as well as limited trials by students of the 2015 chemistry education. Data analysis techniques on media and pedagogic validation using the Guttman scale, while limited trials using Likert scale scoring, with percentages interpreted according to Riduwan'scriteria . The results obtained in the media and pedagogic validation that the product developed is very good, then at the limited trial stage the percentage is $69 \%$ with good categories.
\end{abstract}

Keywords: learning media, e-learning, moodle, Islamic and Science

\section{INTRODUCTION}

Trafficking the 21st century ICT (Information and Communication Technology) is growing very rapidly. This brings tremendous impacts on various sections of life from the field of economics, communications, social, politics, to education. Implementation of ICT becomes a mandatory option that must be adapted in the world of education[1]. Not only on the context of education in general but also penetrate to education specifically, the learning is. The potential utilization of ICT in education is very much of such as to improve access to educational, improving efficiency, and learning quality and teaching (Zubaedah, 2017; Suartama\&Sastra, 2014, p. 2;[2], [3].

According to research conducted by[4], [5]. There are nine principles that can be applied in teaching the skills in the 21st century, one of which is to utilize ICT to support learning. UIN syarifHidayatullah Jakarta in its strategic plan (2017, p. 40) It is also out that in an effort to improve the quality of learning needs to be optimized the utilization of ICT. With the ability to use and integrate ICT in teaching activities, lecturers are expected to deliver Preservice's Teachers meet the competence and skills required in the face of life, world of work and citizenship in the 21st century (Suartama\&Sastra, 2014, p. 3). According to (Wagner, 2010) There are seven competencies and skills required, here: (1) Critical thinking and troubleshooting skills [6], (2) collaboration and leadership, (3) accusations and ability to adapt, (4) initiatives and entrepreneurs, (5) are able to communicate effectively both orally and written, (6) able to access and analyze information, and (7) have curiosity and imagination.

The problem, technology still plays a small role in education (Zubaedah, 2017). According to the results of interviews conducted by the penalty to two UIN Jakarta chemical education students, exposing that as long as most of the educators only investigated the slide media only.For that researcher introduced webbased learning which is one type of application of elearning, through the LMS Moodle application (Modular Object Dynamic Learning Environment).Elearning has several advantages over traditional learning such as providing accessibility and flexibility where learners can be easier to search and acquire knowledge anywhere and anytime, it can also depend on time constraints and space[7]-[12]Zubaedah, 2017; Jan, et al., 2016; Rianto, et al., 2012, p. 3; Mulyati\&Bakri, 2017, p. 25; Herayanti, 2017; (Lan, Damijana, Nina, \& Aleksander, 2015); Unlimited learning is that should be applied in teaching 21stcentury skills, to improve critical thinking, creativity, collaboration and communication.

Moodle is an open-source software that supports implementation of e-learning with an integrated paradigm in which various features support learning can be accommodated.Important features of learning for example: task, quiz, communication, collaboration, and main features that can upload various format learning materials. The integrated paradigm allows students to enter into "digital classrooms" to access learning materials[13]-[18] (Gege\& Made, 2015; Herayanti et al., 2017; 
(Suvorov, 2010); (Manakshe \& Gulhane, 2012); (Sun, 2013). Research conducted by Umek et al. (2017) explained that moodle is one of the most user-friendly open-source software among all the platforms compared, this is also supported by research conducted by Liao et al. (2011); Bahs\&Daoud, 2016. In addition, Moodle supports management, monitoring and evaluation of effective learning processes.

UIN SyarifHidayatullah Jakarta as one of the Islamic Colleges which has the vision of becoming a world-class university with excellence in scientific integration, Islam, and Indonesianness(Renstra UIN Jakarta, 2017). As a university that combines religion and general science, UIN Syarif Hidayatullah is expected to be a centre for the study of science and religion which is transformed into its education curricula and teaching. The distinctiveness in the form of Islamic interaction and general science will also become a distinction that distinguishes it from other campuses. The combination of Islam and general science emerged both in the form of subjects and study programs that were specifically designed and were already underway(Rosyada, 2017).

Islam and Science (IIP) are university character courses that are applied in the SyarifHidayatullah UIN Chemical Education Study Program Jakarta. The IIP course teaches the integration of Islam and Science, especially chemistry to prospective teachers [19]. In IIP courses, prospective teachers are required to be able to integrate Islam in the Learning Implementation Plan (RPP) and chemical teaching material. In addition, prospective teachers were also asked to make teaching videos, articles and proposals for integrated Islamic chemistry. The learning system applied in this course is combining conventional learning with e-learning, this system is known as blended learning.

Student-centred learning is an essential principle of 21 st century learning (Nicholas, 2013), where educators only act as facilitators and mentors who strive to help link the initial knowledge that has been possessed by students with the information to be learned, and help students when they find difficulties in the process of construction of knowledge and skills. In line with Resntra (2017), that UIN SyarifHidayatullah Jakarta is an institution that has implemented student-centred learning. One learning model that can implement the student centre is blended learning(Hermawanto, 2013).

Based on the background described, the purpose of this research is supporting Preservice Chemistry's Teachers To Learn Islamic and Science Using Moodle.

\section{METHOD}

The research design of the 4D model development that follows the path of Thiagarajan et al. These 4D steps have four stages, namely define, design, develop, and disseminate. However, in this study there was no disseminate stage because of the limitations of the researchers.

The define phase is done in five steps. First, the analysis of lecturers and prospective teachers by interviewing later information from the resource person is reduced to a script, then displaying the data by giving a code (coding) which is then made a conclusion. Second, adopting the structure of the contents of the Semester Learning Plan. The three concepts / material with the aim of identifying topics, concepts, and theories presented in the media. Fourth, the formulation of learning objectives. Fifth, the preparation of a benchmark reference test which is divided into two, namely the formulation of tasks and preparation of evaluations.

The design phase consists of four steps. First, designing a draft product with results consists of two forms, namely, flowchart and storyboard. Secondly, the choice of media to be used, the results of the literature review that the reading researcher selected were LMS Moodle which was used as an application for this media. Third, analysis of features in moodle media. Fourth, designing content into media that is divided into two parts, namely the introduction with the homepage and the core which presents a lecture description with 16 meetings.

The development stage consists of four steps. First, the development of moodle media with the resulting components in the form of server, domain, and video hosting. Second, the validation of media and pedagogical experts who then obtained data through validation sheets accumulated based on Guttman's scale criteria presented in Table I (Riduwan, 2013).

Table I. Guttman Scale Criteria

\begin{tabular}{|c|c|c|}
\hline Num. & Alternative Answers & Score \\
\hline 1. & Yes & 1 \\
\hline 2. & No & 0 \\
\hline
\end{tabular}

Furthermore, for the validation calculation, use the following formula:

Percentage of validation results $=\frac{\text { total score }}{\text { maximum score }} \times 100 \%$

(Widoyoko, 2012, p. 110).

Third, revisions are adjusted to validator responses at the expert validation stage. Fourth, the trial was limited to the 2015 chemistry education students who participated in Islamic and Science courses, the acquisition of data was obtained through the instrument of the teacher candidate questionnaire responses and then accumulated based on Likert Scale scoring criteria in Table 2 (Riduwan, 2013). Instrument questionnaire student response questionnaire consists of three aspects of assessment, 
namely; content and material, language used, and graphics and presentation.

Table 2. Likert Scale Scoring Criteria

\begin{tabular}{|c|c|c|c|}
\hline \multirow{2}{*}{ Num. } & \multirow{2}{*}{$\begin{array}{c}\text { Alternative } \\
\text { Answers }\end{array}$} & \multicolumn{2}{|c|}{ Score } \\
\cline { 3 - 4 } & Strongly Agree & Positive & Negative \\
\hline 1 & Agree & 4 & 1 \\
\hline 2 & Less Agree & 3 & 2 \\
\hline 3 & Disagree & 2 & 4 \\
\hline 4 & Very Disagree & 1 & 5 \\
\hline 5 & \multicolumn{2}{|c}{} \\
\hline
\end{tabular}

Then the data obtained is calculated by the answers of all respondents in each item statement with the following formula.

Percentage per item $=\frac{\text { total item score }}{\max \text { item score }} \times 100 \%$

Next, the average percentage value per aspect, then all. Data obtained can be interpreted according to criteria Riduwan (2010, p. 41), presented in Table 3.

Table 3. Screen Interpretation Criteria

\begin{tabular}{|c|c|}
\hline Score Interval & Category \\
\hline $81 \%-100 \%$ & Very good \\
\hline $61 \%-80 \%$ & Well \\
\hline $41 \%-60 \%$ & Pretty good \\
\hline $21 \%-40 \%$ & Not good \\
\hline $0 \%-20 \%$ & Very Poor \\
\hline
\end{tabular}

\section{RESULTS AND DISCUSSION}

The results obtained from the research conducted are as follows.

\section{A. Define}

In the analysis step the educator and student researcher conduct interviews with the lecturers and two teacher candidates who will take part in Islamic and Science courses especially chemistry. Based on the results of interviews with two prospective teachers it is known that the learning media used so far are only limited to the prospective teacher's slide media actively in gathering information. Based on Zubaedah (2017), in the 21st-century educators must prepare their students to be able to have 21 st-century skills, which means educators are required to innovate in teaching and learning including being able to take advantage of new media and technology in learning. The role of educators in the $21 \mathrm{st}$ century must shift from the pattern of "planting knowledge" to the role of facilitator, tutors and gauges for students (Hampson, et al., 2011). The role of educators as learning trainers will provide guidance to help develop students' skills in achieving their learning goals.
Based on the results of interviews with lecturers, information was obtained that the limitations of faceto-face time and the dependence of prospective teachers on the material provided by educators were the cause of the lack of maximum learning process. Overcoming time and space constraints, educators can develop unlimited learning where students can continue to search for and acquire knowledge anywhere and anytime. The use of technology outside the classroom allows students to have forms of learning (Furlong \& Davies, 2012). In addition, the lecturer also explained that the use of instructional media is not maximal but has implemented electronic learning such as Edmodo, collage, and quiver, only applied for certain classes.

The results of the analysis of educators and preservice teachers' encourage researchers to utilize elearning with web-based learning media. Kuimova, et al., (2016) explained that e-learning is a tool that can increase the knowledge and quality of education, besides that e-learning also provides flexible conditions (such as freedom of time) that can increase independence, self-motivation, responsibility, and discipline.

Preparation of the structure of contents, concepts or material, as well as the formulation of learning objectives researchers adopted from the Semester Learning Plan (RPS) provided by lecturers of Islamic and Science subjects, especially chemistry, this is because the making of RPS is the responsibility of educators who will later be sponsored. While the benchmark reference test is divided into two parts, namely the formulation of tasks in the form of material assessment guidelines, lesson plans and teaching videos, and the preparation of evaluations in the form of quizzes and standards for proposal evaluation.

The results of the discussion with lecturers in Islamic and Science subjects, especially chemistry, applied a mixed learning system, known as blended learning. Patel \& Patel (2017) revealed that blended learning is combining learning in the classroom with e-learning, this can increase the access and flexibility of students so that the system is suitable for higher education. Hermawanto (2013) add, that Blended Learning is one of the learning strategies that can implement based learning.

\section{B. Design}

This stage is the stage of content design or content of contake that holds how users will interact. In the draft design of the media drafts formed two forms, flowchart as a sequence of programs and storyboard as a detailed product description of.

The next step of the selection of software to be used, after the association of reading the literature review on the advantages and disadvantages of various learning management system (LMS) then 
researchers choose moodle. The reason, Moodle is an open-source software that supports implementation of e-learning with an integrated paradigm where various learning support features are easily can be accommodated. Important features of learning for example: task, quiz, communication, collaboration, and main features that can upload various format learning materials. The integrated paradigm enables learners to enter "digital classroom" to access learning materials (Gege\& Made, 2015). Research conducted by Umek et al. (2017) explaining that the moodle is one of the most user-friendly open-source software among all the platforms compared, it is also supported by research conducted Liao et al. (2011); Kareal\&Klema (2006); Bahs\&Daoud, 2016. In addition, Moodle supports the management, monitoring and evaluation of effective learning processes.

Moodle's determination as an application in the product developed then the next step is the researcher analyzing the features contained in the moodle, with the aim of knowing what features can support elearning. In principle the moodle contains two things, ie resources and activity. Resources is a variety of static learning materials that matter which material does not require interactions with learners, consisting of text pages, web pages, links to files or sites, directories, labels and IMS packages. While Activity is learning material requiring interaction with users, such as assignment and quiz, discussion forums, and chats(Suartama\&Sastra, 2014, p. 98). A course certainly not only contains static learning materials, it will be necessary active learning that supports the realized learning of integrated learning, the results of feature analysis displayed in Table 4.

Table 4. Moodle Feature Analysis

\begin{tabular}{|c|c|}
\hline Feature & Information \\
\hline Login \& & Is a link to enter and exit the media. The \\
\hline \multirow[t]{4}{*}{ Logout } & $\begin{array}{l}\text { categories for media entry and exit are divided } \\
\text { into } 3 \text { according to each user and password, } \\
\text { i.e.: }\end{array}$ \\
\hline & a. Login/logout as admin \\
\hline & b. Login/logout as a prospective teacher \\
\hline & c. Login/logout As a lecturer \\
\hline Course & $\begin{array}{l}\text { Contains the translation of Islamic and Science } \\
\text { courses that can be accessed independently by } \\
\text { students in accordance with the instructions } \\
\text { given. }\end{array}$ \\
\hline $\begin{array}{l}\text { Downloa } \\
\text { d }\end{array}$ & $\begin{array}{l}\text { Display the download link to get material and } \\
\text { other lecture needs. }\end{array}$ \\
\hline Quiz & $\begin{array}{l}\text { Contains practice questions at the end of each } \\
\text { meeting that has been designed according to } \\
\text { needs. }\end{array}$ \\
\hline File & $\begin{array}{l}\text { Contains material or other lecture files in word } \\
\text { form that can be downloaded. }\end{array}$ \\
\hline Folder & $\begin{array}{l}\text { Contains two or more files and can be } \\
\text { downloaded. }\end{array}$ \\
\hline $\begin{array}{l}\text { Assignme } \\
\text { nt }\end{array}$ & $\begin{array}{l}\text { Students can upload assignments that have } \\
\text { been done in various formats into the media. }\end{array}$ \\
\hline Page & $\begin{array}{l}\text { Contains video lesson material that is } \\
\text { connected to YouTube. }\end{array}$ \\
\hline
\end{tabular}

After the setting of the feature to be used the next step of the penalty designed the content of the design to the media, which is divided into two drafts that is the introduction of the homepage and the core containing the general lectures of the course by supplying 16 meetings. On the homepage of the vision-mission of UIN Jakarta, Video of the use of media use, Video is laden insight that is inspiring Islam and science, as well as some main menu provided by Moodle. While at the core or call it with course, the first meeting of students is presented RPS as the benchmark of the study, in the form of the video, the task of assessment, and the quantity of the design. This content is designed to be found in Fig 1 and 2 .

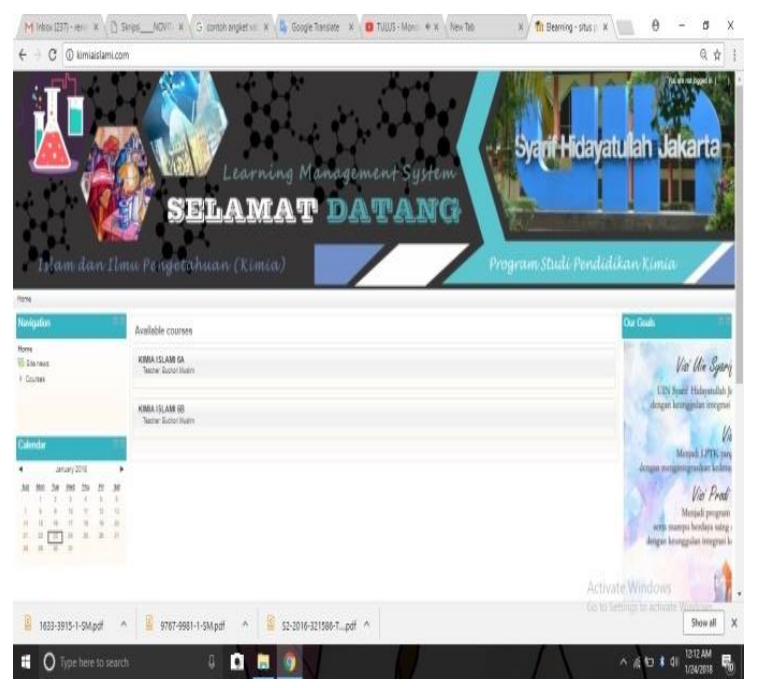

Fig. 1. Homepage

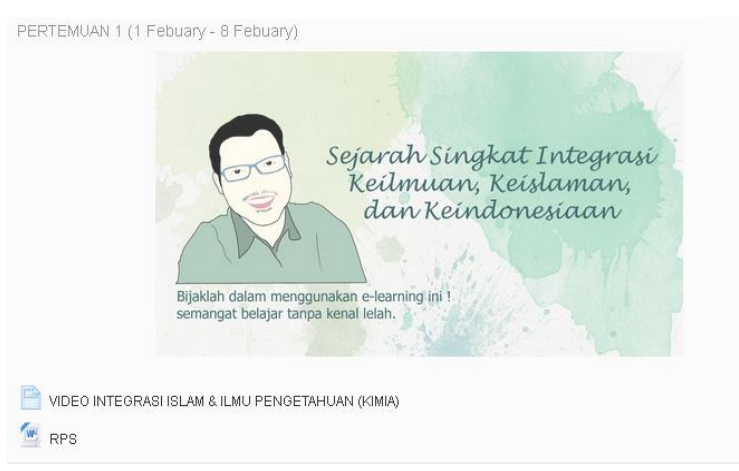

Fig. 2. Display Course

\section{Development}

Research and development is a research method used to produce certain products, and test the effectiveness of these products (Sugyiono, 2016, p. 297). The first step taken is the development of moodle media, this development is carried out online so that Islamic learning and science in particular chemistry can be accessed wherever and whenever so students can learn more easily and flexibly. The results of moodle development can be seen in Table 5 . 
Table 5. Moodle Development Result

\begin{tabular}{ll}
\hline $\begin{array}{l}\text { Development } \\
\text { Results }\end{array}$ & Explanation \\
\hline $\begin{array}{l}\text { Hosting } \\
\text { server }\end{array}$ & $\begin{array}{l}\text { Hosting server is a device for uploading all } \\
\text { the website building files that have been } \\
\text { created. In this web-based learning media } \\
\text { researchers use paid webs because they } \\
\text { avoid server down, the hosting that the } \\
\text { researcher uses is hostinger.id. }\end{array}$ \\
Domain & $\begin{array}{l}\text { Domain is naming internet web pages. This } \\
\text { naming is used to direct or search for }\end{array}$ \\
& "machines" that are used to store a user's \\
& web page. Domain names can also be said \\
& as "home addresses". In this media, the \\
domain used is .com, this domain is used \\
because the price is affordable and easy to \\
be desired by web users, while for IP \\
addresses (IP \\
namelywww.kimiaislami.com. \\
Researchers make Islamic videos and \\
Chemistry as an introductory video of \\
courses and video guides for using e- \\
learning. editing videos with the wonder \\
share filmora application, then uploading \\
videos to youtube and synchronizing to \\
web-based learning media.
\end{tabular}

An application program that can transform learning media into web forms provides another advantage, which is to improve the ranking of the webometrics version, which measures the progress of higher education through its website. However, it is unfortunate that this media has not used the institutional domain because SyarifHidayatullah's UIN server is not ready, so researchers use a paid domain with the hope that it can become a reference for educators.According to Perdananugraha (2012), webomatric only assessing an independent institution's domain, meaning having an intact domain that reflects the institution.

The next stage is media validation carried out by two media experts and one pedagogic expert. The purpose of this validation is to find out the weaknesses and strengths of the product.

Table 6. Validity Of Products

\begin{tabular}{|c|c|}
\hline Validator & Results \\
\hline Media Expert I & $95 \%$ \\
\hline Media Expert II & $100 \%$ \\
\hline Pedagogist & $100 \%$ \\
\hline Average Percentage & $98,33 \%$ \\
\hline
\end{tabular}

Based on the validation calculation, the data obtained was presented with criteria according to Riduwan (2013), the percentage of $98.33 \%$ was included in the category of "very good". To improve product suggestions, the validator is used as a consideration for researchers in making product revisions.

\section{Limited Trial}

Media that has been repaired and refined, then examined again whether this media is suitable to be used or not in certain situations. The trial phase was carried out for 70 teacher candidates from the 2015 UIN Syarif Hidayatulla Jakarta education students. Questionnaires contain 46 statements which cover aspects of content and material, aspects of language, and graphical aspects of presentation, then analyzed into data on student responses to media components which will later be interpreted by criteria according to Riduwan (2010, p. 41). Learning media evaluation aims to see whether the use of media can shape or influence student behavior or not, and find out whether the media used is effective or not (Zainiyati, 2017, p.185).

The results of questionnaire data processing responses of students can be seen that the three aspects of the assessment component of student responses to web-based learning media developed have good criteria with an average percentage of $69 \%$. In the content and material aspects get the lowest percentage of $64 \%$, while the language aspects used in e-learning and graphics and presentation in elearning obtain the same average percentage of $71 \%$.

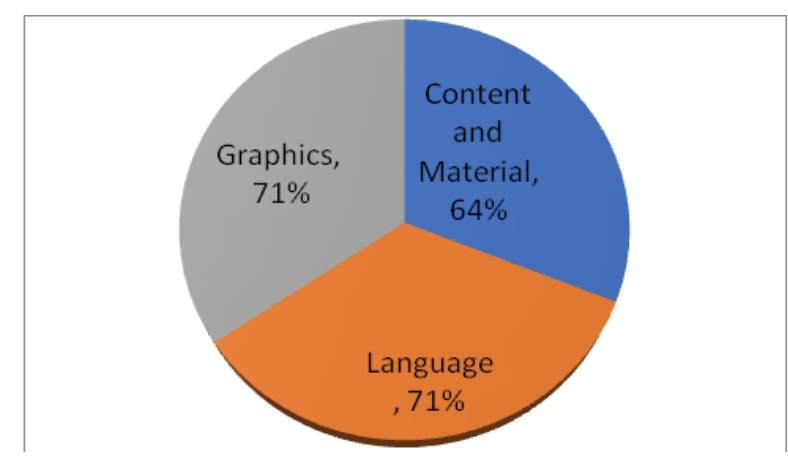

Fig. 3. Results of Preservice Chemistry Teachers Response

Content and material get the lowest percentage, with a percentage of $64 \%$ but still in the good category. The researcher made the material in the form of video, because it refers to research Mark et al (2011) "Learning uses video media to direct the concept of thinking more effectively than using print media". Positive things about the video were also expressed by meij (2014), through video it will provide a quick space for instructing users about the procedure, leading to questions that appear effectively and are easy to design.

According to umek (2017), said the effectiveness of e-learning involves user-technical interactions or known as socio-technical systems, which means that e-learning does not only depend on aspects of people (eg students, teachers, and interested stakeholders) or technical systems (for example, content, LMS technology, as well as other content processing tools)[20]. In summary e-learning is a complex process and depends on socio-technical interactions. 
This is confirmed by Sari (2014), which according to him the success of web-based learning also depends on the ability and motivation of the learner.

The learning experience of Edgar Dale who said that, people remember $10 \%$ of what they read; $20 \%$ of what they hear; $30 \%$ of what they see; $50 \%$ of what they see and hear; $70 \%$ of what they write and say; $90 \%$ of what they say and do. Getting to see and hear is still in passive learning, whereas if you say and do it includes active learning. In this learning system, using a blended learning model where the interaction in blended learning according to Sari (2014) including active learning The results of research in America show that blended learning is $30 \%$ better, $40 \%$ shorter time, and 30\% lower cost (WardianadalamRusman et al., 2011, p. 249). Blended learning is able to provide interaction between students and students and students with better lecturers. This interaction can occur through various opportunities, both conventional classes and online classes.

In the four pillars of 21 st century learning namely, learning to know, learning to do, learning to be, and learning to live together. Explain that one of the competencies and skills in that aspect is communication and collaboration skills, this capability can be developed through experience that is in school, between schools, and outside of school. Chat facilities provided by the moodle talk about educators and students to communicate directly without limits of distance and space, this fosters interactive discussion between the two users. According to[21] it allows students to improve communication and collaboration skills. However, it was very unfortunate in this study that discussion through online had not yet been studied, so that the researcher suggested that further research would use the chat feature more.

Kasali (2013) said "Challenges of Indonesia in the 21 st Century" there are six main drivers that must be considered for educational technology:

1) Mobile learning, every learner hopes to learn anytime and anywhere.

2) Cloud computing, information can be accessed in any device.

3) Collaborative learning, structured student project.

4) Mentoring, quality of mentoring that makes a difference.

5) Blended learning, face to face and online learning.

6) Student-centred, shift that is centered on educators to students.

In connection with the explanation above, the challenge of educators is to be able to prepare their educators to live in the digital age, one of which is to apply blended learning models in learning.

\section{CONCLUSION}

Instruction should be student-centred as the main principle of 21 st-century learning, where educators only act as facilitators and mentors who try to help link the initial knowledge they have with the information the prospective teacher will learn, and help when finding difficulties in the process of constructing knowledge and his skills. Blended learning can implement this, for that in addition to face-to-face learning colleges need to apply webbased learning one of them by using moodle. In a limited trial conducted for the 2015 chemistry education teacher candidates, the moodle media used to support the study of Islamic and Science subjects received a percentage of $69 \%$ and then interpreted and entered in the good category.

\section{REFERENCES}

[1] N. Duţă and O. Martínez-Rivera, "Between Theory and Practice: The Importance of ICT in Higher Education as a Tool for Collaborative Learning," Procedia - Soc. Behav. Sci., vol. 180, pp. 1466-1473, May 2015.

[2] M. Bialik, C. Fadel, B. Trilling, P. Nilsson, and J. Groff, "Skills for the 21st Century: What Should Students Learn?," Cent. Curric. Redesign, 2015.

[3] C. L. Scott, "THE FUTURES OF LEARNING 1:IrWHY MUST LEARNING CONTENT AND METHODS CHANGE IN THE 21st CENTURY?," EDUCATION RESEARCH AND FORESIGHT • WORKING PAPERS. 2015.

[4] A. R. Saavedra and V. D. Opfer, "Teaching and Learning 21st Century Skills: Lessons from the Learning Sciences," Asia Society, 2012.

[5] A. Aristovnik, "THE IMPACT OF ICT ON EDUCATIONAL PERFORMANCE AND ITS EFFICIENCY IN SELECTED EU AND OECD COUNTRIES : A NON-PARAMETRIC," Turkish Online J. Educ. Technol., vol. 11, no. 3, pp. 144-152, 2012.

[6] Muslim, B. (2014). Pengaruh Model Pembelajaran Pemecahan Masalah Terhadap Keterampilan Berpikir Kritis Dan Efikasi Diri Siswa Pada Konsep Hidrolisis Garam. Bandung: UPI Bandung

[7] S. Chootongchai and N. Songkram, "Design and development of SECI and moodle online learning systems to enhance thinking and innovation skills for higher education learners," Int. J. Emerg. Technol. Learn., vol. 13, no. 3, pp. 154-172, 2018.

[8] M. Carr, "The Online University Classroom: One Perspective for Effective Student Engagement and Teaching in an Online Environment," J. Eff. Teach., vol. 14, no. 1, pp. 99-110, 2014.

[9] R. W. H. Lau, N. Y. Yen, F. Li, and B. Wah, "Recent development in multimedia e-learning technologies," World Wide Web. pp. 189-198, 2014.

[10] V. Arkorful and N. Abaidoo, "The role of e-learning , the advantages and disadvantages of its adoption in Higher Education .," Int. J. Educ. Res., vol. 2, no. 12, pp. 397-410, 2014.

[11] D. Weaver, "Academic and student use of a learning management system : Implications for quality Academic and student use of a learning management system : Implications for quality," Australas. J. Educ. Technol., vol. 24, no. 1, pp. 30-41, 2008. 
[17] U. Njoku, "Information and communication technologies to raise quality of teaching and learning in higher education institutions and learning in higher education institutions," Int. J. Educ. Dev. using Inf. Commun. Technol., vol. 11, no. September, pp. 122-147, 2015. impaction System : Factors affecting impact Ahmad Al-adwan Jo Smedley," Int. J. Educ. Dev. using Inf. Commun. Technol., vol. 8, no. 1, pp. 121-135, 2012.

[13] S. O. Essuman, E. K. Asante, and P. A. Boateng, "MOODLE-BASED PREPARATION OF COURSEWARE MATERIALS FOR A MASTERS PROGRAMME AT THE UNIVERSITY OF EDUCATION, WINNEBA," Int. J. Educ. Learn. Dev., vol. 3, no. 4, pp. 55-66, 2015.

[14] C. Costa, H. Alvelos, and L. Teixeira, "The use of Moodle elearning platform: a study in a Portuguese," Procedia Technol., vol. 5, pp. 334-343, 2012.

[15] M. C. Garbin, S. Ferreira, C. O. S. Mendes, E. Ogasawara, and J. Macario, "Adaptation of the Moodle for application in distance education course at the state university of campinas," Procedia - Soc. Behav. Sci., vol. 46, pp. 2514 2518, 2012.

[16] A. S. Al-ajlan and M. A. A. Hammoudeh, "Enhancing ELearning System in Qassim University by Implementing Moodle as a Tool," IJCSNS Int. J. Comput. Sci. Netw. Secur., vol. 16, no. 9, pp. 7-14, 2016.

[18] M. Dougiamas, "requirements," Electron. J. English as a Second Lang., vol. 13, no. 2, pp. 1-11, 2010.

[19] Muslim, B., Agung, S., \& Zukhrufian Al Islam, R. (2017). Chemistry Teacher's Perception About Integration Of Islam And Chemistry. International Conference On Education In Muslim Society (pp. 168-183). Jakarta: FITK Press.

[20] N. S. Çrak and H. Karaaslan, "No Title," nternational J. New Trends Educ. Their Implic., vol. 10, no. January, pp. 19-26, 2019.

[21] N. W. Abdulmajid and B. R. Setiadi, "PEMANFAATAN SOCIAL WEB ENVIRONMENT DALAM MENCIPTAKAN STUDENT- CENTERED LEARNING DAN PENINGKATAN KETERAMPILAN SISWA PADA," Semin. Nas. Univ. PGRI Yogyakarta 2015. ISBN 978-602-73690-3-0, 2015. 